\title{
The Tiv Poet And Heroism: A Study of Inyamtswam Songs
}

\author{
Emmanuel Lanior Amase (Corresponding author) \\ Department of Language and Communication Studies, Federal University Dutsin-ma, Nigeria \\ Aondover Alexis Tsavmbu \\ Department of Language and Communication Studies, Federal University Dutsin-ma, Nigeria \\ Aondover Theophilus Kaan \\ Department of Language and Communication Studies, Federal University Dutsin-ma, Nigeria
}

\author{
Received: 06-10-2015 \\ Accepted: 20-11- 2015 \\ doi:10.7575/aiac.ijclts.v.4n.1p.58 \\ URL: http://dx.doi.org/10.7575/aiac.ijclts.v.4n.1p.58
}

Published: 05-01-2016

\begin{abstract}
Heroic poetry, particularly that of the inyamtswam extraction, is not just popular but fundamental to the existence of the Tiv people. In this paper, we have attempted to show that aside from providing a channel for the people to express their love for competition, heroic poetry corrects social vices, performs didactic functions, propagates the people's culture and serves as a veritable means of entertainment. It also facilitates the link with the ancestral world. In this age when advances in Information Communication Technology (ICT) have turned the world into a global village, we believe there is the risk of the values inherent in Tiv heroic poetry being corrupted and even eroded unless such works as this present one are sustained.
\end{abstract}

Keywords: Tiv, Oral Poetry, Heroism, Heroic Poetry, Prestige

\section{Introduction}

The Tiv are the most populous ethnic group in Benue state, Nigeria. The name Tiv is regarded as the name of a real person who is held as the father of all Tiv. According to Rupert East (2003), Tiv had only two sons, Ipusu and Icôngo. These two form the two main branches of the genealogy found in Tiv land. Ipusu consists of Shitire, Ukum, Jemgbagh and Jecira while Icôngo comprises Tongov, Ugondo, Ikurav, Nôngov, Iharev, Masev and Turan. This classification accounts for the social and political organization of the Tiv society.

Tiv society is made up of kwav (age-groups). In the various age-groups, members engage in active healthy competitions such as hosting of prestigious dance festivals, organization of community labour force and monetary contributions for the development of their communities. Religion is an essential aspect of the life of a Tiv man. This religious belief revolves around akombo (divinities) and Tsav (witchcraft). Among the Tiv, witchcraft is an acceptable way of maintaining order in the community, if it is not used unilaterally.

Marriage is very significant in the life of the Tiv man. This is because the wife/wives and their children provide the much needed labour for effective work on the farm, since the major occupation of the Tiv is farming. In fact, the size of a man's family determines his farm size and of course, the wealth he acquires. No matter how wealthy a Tiv man may be, if he is not married, he is by traditional standards considered irresponsible. His social status is thus greatly reduced and he cannot therefore compete with his age-mates. Being married is thus a pre-requisite for hosting the inyamtswam (prestigious) dance festival. Bachelors cannot host the festivals because the wife must perform alongside her husband.

The traditional African environment is generally poetic because it is replete with occasions that call for poetic performances. Hardly does an African engage in any activity without one form of poetic rendition or the other. This means the African's poetry is intricately woven in his day-to-day life activities. Tiv poetry is thus, "incorporated in the tribe's way of life, and deals with its day to day issues and problems of life"(Jenkwe, 1). The Tiv have their oral literary pieces and several traditional dances which are performed with songs in their communities. These include: Swange, Ange, Girinya, Ibyamegh, Ingyough, Inyinya, Ivom, Inyamtswam, just to mention but a few. Out of these, Inyamtswam, Ivom, Inyinya, Girinya and Ibyamegh are regarded as prestigious (shagba) dances because they have the potential of enhancing a man's prestige. Usually, the different dances in Tiv land are categorized in their historical and artistic contexts by well-chosen names that relate them to their function, history or artistic requirement.

Several reasons account for the organization of prestigious dance festivals. First and foremost, the Tiv are a proud people who take delight in displaying their might and wealth at the slightest opportunity. They see poverty as an evil that must be subdued at all cost. One's ability to achieve this feat is thus considered as a heroic act that calls for a celebration. It is for this purpose that the Tiv have designated some dances as prestigious or heroic dances.

Heroic dance festivals also serve as a way of encouraging hard work and dedication to one's occupation. In Tiv context, a person is considered a 'man' when he is able to host at least one of the several prestigious dance festivals. In fact, 
some of the songs contain derogatory remarks about other indolent members of the community, especially the host's age-mates. This act gingers those indicted to work harder in order to get out of poverty.

Amar mirin also takes place either to welcome a new wife or to celebrate an old favourite wife. Both the host and his wife perform the dances and also feature prominently in the festival songs. Sometimes, too amar mirin is held simply to display newly acquired higher status and to announce one's entry into a new class. Also, dances serve as an outlet for physical and emotional release. The nature of the Tiv man's major occupation (farming) puts him under a lot of stress which is relieved in the course of dancing.

The focus in this paper is on heroic poetry performed at amar inyamtswam (dance concerts). These songs extol the virtues and heroic exploits of the celebrants as well as other prominent Tiv sons or daughters. Heroic poetry preaches virtues like patience, hard work, honesty, brotherhood, sympathy and kindness. The Tiv use this oral art form to foster unity and also enhance development in their society.

Amar mirin literally means organizing a traditional dance festival. According to Tiv history, the practice of amar mirin is as old as the existence of the Tiv. From time immemorial the Tiv have always found dances as a way of expressing their joys or excitement. Sometimes too, dance festivals are organized to commemorate certain important historical events in Tiv land.

\section{Theoretical Considerations}

This paper is premised on the functionalist approach to oral literature. This approach looks at the utilitarian value of literature and does not believe in the idea of art for art's sake. This school concentrates largely on 'function', in particular on the function of stabilizing or validating the current order of things. The functionalists are interested in oral literary form only if they have a clear social function to perform in the society. These functions could be to educate, draw a moral, or warn people against the breaking of norms in the society. We therefore find this approach suitable for this paper. The data used in this study was randomly collected from the field, transcribed and then translated for analysis.

\section{Tiv Heroic Poetry}

Tiv heroic songs have some nobility because they are performed at occasions that are convened to demonstrate the higher status attained by the celebrants. They are praise songs therefore they are very rich in metaphor and exaggeration.

In this paper, we have undertaken a thematic, poetic and stylistic analysis of some selected praise/heroic songs with a view to bringing out their function and literary value.

It is important to note that heroism in this context is different from the European classical heroic literatures. The heroes here are not gods or descendants of gods. They also do not necessarily possess supernatural powers nor do they fight against supernatural beings. "In short, they are ordinary human beings engaged in ordinary human activities (Kunene $\mathrm{xvi}$ ). The poet then figuratively uses metaphor, imagery and symbolism which transport these ordinary activities to an extra-ordinary level. The hero could be described as a monster or a terrible creature destroying opponents.

Inyamtswam, which literally means a dangerous animal or beast is a dreaded masquerade. In this context however, the use of the word inyamtswam is metaphorical. It connotes that the celebrant has become inyamtswam by virtue of his achievements, therefore other people dread facing him in prestige competitions.

Heroic songs do not only praise and extol the good attributes and outstanding feats of the celebrants, but also condemn vices in the community like envy and jealousy as we see below:

Tiv

\section{English}

Ityô yam nahan zee ooo, My people, its not so,

$\begin{array}{ll}\text { Abagi wan u Makaa } & \text { Abagi, son of Makaa } \\ \text { Tar wen ne mase shin } & \text { This land of yours, only has } \\ \text { Iyuhwe, ityô yam, } & \text { Envy, my kinsmen, } \\ \text { Ka an a kura ne tar? } & \text { Who will safeguard your land? }\end{array}$

In the above excerpt, the singer reprimands his kinsmen for allowing jealousy and envy to take over the land. Baffled by this situation, the singer asks rhetorically: "who will safeguard your land?"

Consequently, nobody is willing to support another to succeed as the people conspire to pull down prosperous sons of the community; a situation which the songster finds disappointing. The singer believes that development will come to the land, only if the people eschew envy and jealousy, otherwise their land is heading towards a precipice.

It is also common knowledge that in communities that are full of envy, rumour mongering and gossip are rife. Those struggling hard to prosper become objects of gossip as shown in the next excerpt:

Tiv

Zaki wase kpamor

Tyozer Agera,

\section{English}

Our king, the man of grandeur

Tyozer Agera, 
Nenge shawon;

See the irony of life;

Ka we za shir ayou ave

If you don't struggle,

Kpa, Zaki

But, Zaki.

Ityô i teman imôngo awe, People gossip about you.

Er u kungu ichan

That you are poor;

U kungu bee ivu ve,

As poor as unkempt gray hairs.

Wa kaa di we u nôngo

If you decide to struggle,

Kpa u kpera iyongo ibo

But you incur the wrath

Hen ityô ve;

Of the people;

We a zer ikyondo a engem If you wear nice clothes,

Kpa ukpera iyongo ibo But you incur the wrath,

Hen ityô ve; $\quad$ Of the people;

We a nema sule $\mathrm{u}$ a kehe If you have a large farm,

Kpa u kpera iyongo ibo But you incur the wrath

Hen ityô ve,

Of the people;

Ityô i ôron we iger,

They derogatorily

Er we u hingir tor

Say, you have become king

Or a kuma je ga

No one can match you.

The above excerpt comments on the ironical situation where indolent people become objects of gossip and ridicule, while those working hard also incur the wrath of the community. The wealthy are envied for possessing so much property, instead of being encouraged. The rampant cases of land disputes in Tiv land are largely due to jealousy, envy and greed, thus leading to wanton destruction of lives and property. The singer however urges those working hard, not to be deterred by their detractors. The song condemns envy, jealousy and gossip. It prepares the ground ready for the appearance of achievers at the occasion.

The inyamtswam masquerade usually symbolizes the might and prowess of the dancers who are often great achievers. Non-achievers or non-initiates of inyamtswam are usually referred to as 'women' or children in their communities. They must therefore make way for the dreaded inyamtswam as it appears in the arena as we see below:

Tiv

Ior zua har shin tembe,

Yô mlu ôron,

Me shi ve na ian,

Hen tembe fefa, gayô,

Inyamtswam kange

Bee ve;

$-\cdot-$

Inyamtswam gba van ve ooo!

Ior i sor ian doo-doo,

Mbayev ve yevese ooo-oo.

\section{English}

People have gathered in the arena,

So, I am warning,

That they should make way

In the arena quickly,

Otherwise, inyamtswam

Is set to emerge;

Inyamtswam is coming ooo!

People should make way properly,

Children should run-ooo.

One's heroic status is also demonstrated by the involvement of the cosmic forces like the sun, thunder, rain and lightning. The poet tells us below that as Ityôsongo Aga appears in the inyamtswam (masquerade) for a performance, there is thunder and lightning and the sun is dimmed. This development is symbolic of the prowess and heroic status of the celebrant. The reactions of thunder and the sun signify the acknowledgement of the celebrant's fame and prestige by even the cosmic forces, as stated below:

Tiv

Ityôsongo Aga due

Shin tembe, mnenge

Aôndo dura, kume

Dighin, kume pir iyange.

\section{English}

Ityôsongo Aga appeared

In the arena; I saw

Thunder and lightning,

Dighin, and the sun was darkened. 
The next excerpt below is another public display of the celebrant's heroism and bravery, as he is said to have unsheathed his sword to cut off a tiger's head:

Tiv

Ityôsongo wan u Aga,

Nyôr ôôv sanker

Er wen a gber

Nom anyam ityough,

Wen a nam gundu.

\section{English}

Ityôsongo, son of Aga

Unsheathed a sword

That he would cut off

A tiger's head.

And give me the carcass.

The above excerpt is a rare display of heroism by the celebrant. He has become inyamtswam by virtue of his achievement and can even kill a tiger. The scenario depicted here is best understood metaphorically, as the tiger about to be beheaded is simply amar (dance concert) that the wealthy celebrant intends to convene for the singer, who cannot afford the cost on his own. In Tiv culture, those who have sufficient wealth do not just stop at organizing amar (concerts) for themselves, but also organize for their indigent relations. By doing so, their pedigree continues to rise and their fame equally extends beyond their immediate communities.

Heroic songs do not only praise personalities, but also explore the philosophy of life and its absurdities. The songs equally demonstrate the Tiv belief in the inevitability of death as shown in the next excerpt:

Tiv

Wanyam ooo,

Mo mwa tsav ken vanger,

Kpa mo mkav

Kwagh shin ishima ze,

Orgee mase yemen nee.

Me, hile zaan ooh,

Wan Chember, kwase

Ingyôr va tôô kweregh

Shin gbenda,

I de un a nyôr ooo.

We, Agber Aga Kpehe,

Oooh! Ahoo ne ityô i

Jina due jinge war,

Yô nenge ase,

Ônmbachom gba tar ve.

Avungu kar hemen

A tar, ua doo

Shawon ze ooo,

Ka ifan i Muufu.

\section{English}

Wanyam ooo,

I am full of wizardry

But was not vigilant enough,

So, Orgee has

Finally departed.

Just lead the way ooh!

Daughter of Chember, woman

Ingyôr started wailing

From the road;

Allow her into the compound ooo.

You, Agber Aga Kpehe,

Oooh! Alas! you kinsmen of

Jina have consented to killings

So, look at this;

Mbachom children have destroyed the land.

Owls have become leaders,

The land

Can't prosper ooo.

It is Muufu's curse.

The singer in the above excerpt laments the death of his dear one, Orgee, but is quick to add that Orgee is merely leading the way on a journey that all humanity must embark upon. He blames the elders of Mbachom for the frequent deaths in the land and accuses them of not being vigilant enough, thereby allowing some unscrupulous elements to use witchcraft and kill prominent sons of the land. The poet figuratively says, 'owls' have taken over leadership of the community so, there cannot be any good in the land.

Owls are nocturnal birds that the Tiv associate with evil. They are therefore a metaphor for bad leadership that breeds evil. The issue of death among the Tiv is usually linked to witchcraft because in Tiv cosmology, people do not just die; they are killed by the mbatsav (witches and wizards). The singer advises Mbachom elders to rid their land of evil acts in order to prosper.

The tone in the next excerpt changes as the songster expresses joy that his kinsmen, Yaav have convened amar,(dance concert) and so there is drumming and dancing:

Tiv

Ne on Turan cii,

Tile mo kaa neo ooo!

\section{English}

You, Turan children,

Let me tell you - ooo! 


$\begin{array}{ll}\text { Shi mo kaa ne ooo } & \text { And tell you - ooo, } \\ \text { Ne ityô yam Yaav, } & \text { You, my Yaav kinsmen } \\ \text { Ityô yam i mir amar } & \text { My kinsmen organized a concert, } \\ \text { Yô mlu kaven anom, } & \text { So I am boasting, } \\ \text { Torde m yar amar } & \text { Torde, I attended the concert, } \\ \text { Tsa ijô-genga sômôn; } & \text { Drum beats rent tha air; } \\ \text { Kôkô zômôn iyol } & \text { Kôkô twisted his body } \\ \text { Shin gema oooh. } & \text { In the grave oooh. }\end{array}$

In the above excerpt, the hero, Majir Ker Zungur has proudly convened amar (concert) to uplift the name of Mbachom kindred. In praising the convener, the singer uses hyperbole in lines nine and ten above when he says that, the drumming was so loud that it made Kôkô, the celebrant's late grandfather to "Twist his body/In the grave". The significance of the exaggeration is not only to emphasize the intensity of the drumming, but also to show the acknowledgement of the celebrant's heroic feat by his ancestors.

The actions of thunder, lightning and rain are again highlighted in the praises of yet another icon of achievements in the land, called Tyobugh Gbachi. The singer tells us that he is dressed in the brightly coloured anger cloth, and as he steps majestically into the dance arena, thunder rumbles in the sky. The action of thunder is obviously in recognition of the great feats attained by the addressee. He is indeed a man of no mean achievements, and the singer concludes that Uifande clan has indeed begotten real men of valour and enviable achievements. The poet states:

\section{Tiv}

Tyobugh Gbachi

U chir anger ikyondo iyol,

U ngu van amar,

Aondo kume wura

Yar-yar-a-ah.
English

Tyobugh Gbachi

You are dressed in anger cloth

And are coming to the concert,

Thunder keeps rumbling

Gloriously.

The next excerpt is in praise of yet another traditional heavy weight, Nyitamen Damkor, who is held in high esteem by his community. He is a man of many achievements, whose arrival at the amar (concert) arena is being heralded by the drumming of the indyer as we see below:

\section{Tiv}

Nyitamen Damkor

Ngu van amar,

Indyer i Damkor

Nyin tsa imo.

\section{English}

Nyitamen Damkor

Is coming to the concert,

Damkor's indyer (slit-log drum)

Sounded throughout the night.

Indyer, which is mentioned in line three above, is a huge slit-log drum that is regarded as a sacred instrument in Tiv land. The Tiv also believe that to own an indyer, one must have some supernatural powers as the demands for its possession are beyond an ordinary man. It is usually sounded to announce deaths of very important and respectable elders of the land. It can also be sounded at some other important cultural occasions. For the indyer to be sounded at the instance of a person's presence at a gathering is indeed a big honour given to that personality. The indyer being referred to here is owned by Damkor, the celebrant's father, therefore both the father and son are heroic personalities.

Tiv heroic poetry practitioners make copious use of metaphors or metaphorical expressions both in comparing their objects of praise to symbols of strength, and in making philosophical statements, as we see below:

\section{Tiv}

Uyina u Kwangi Ukor Asama,

Tar yô ka

Wan ishegh, ka u a

Tsea or yô

Nan ta kor.

\section{English}

Uyina Kwangi Ukor Asema,

The world

Is a bottle gourd,

If one is lucky,

He hooks a rope on the neck.

'The world' in line two above is metaphorically referred to as "A bottle gourd". According to the singer, one's success in life is also dependent on luck or the benevolence of fate. The gourd is a metaphor for life and its struggles. If anyone 
is able to "hook a rope on the neck", then that person is bound to prosper. The non-achievers are thus those whose 'ropes' or struggles in life are yet to hook on the gourd's neck.

It was earlier noted in this paper that organizing amar (dance concert) in Tiv land is usually done on a competitive basis. This is why latter conveners try to surpass the former. Also, in order to distinguish themselves and out-class their age-mates, some achievers convene amar (concerts) not just for themselves but also for their indigent kinsmen or relations. This is the scenario depicted in the excerpt below:

\section{Tiv}

Tamen, wan u Daamom

A er shagba

Yôr bee ooo,

Hide wa wanigba

$\mathrm{Na}$ amar, man,

A yilem icham

Mve ye.

\section{English}

Tamen, son of Daamom

Has finished celebrating,

His prestigious status,

And has organized a concert

For his maternal kinsman,

And has invited me to sing.

That's why I've come.

The songster praises the convener of the two amar sessions (concerts) for the double celebrations. He must be wealthy indeed, because the financial involvement for one festival alone is usually not a child's play.

In the next excerpt, the singer is overwhelmed by the calibre of personalities that have converged at the inyamtswam dance arena. He confesses that he lacks the qualification to even sing about them, so he is merely mentioning a few of them. He cannot recall all their past deeds and achievements so all he is doing is simply "passing by the sides" of the rapid. He sings:

Tiv

Ishol yar haa ngee yum

Iyuhwa ne kumbur,

Gande, mngu

Karen i sha

Akur-akur ooo;

Sha akur-akur

Di zan-zan, u ningir.

\section{English}

The dance festival is too crowded

This rapids is turbulent

And too dangerous.

I am passing

Only by the sides ooo;

Only by the sides

And going round.

The 'rapids' in line three above is a metaphor for the calibre of powerful, heroic men and other great achievers present at the occasion. The singer sees himself as not even worthy to introduce the dignitaries present at the occasion. Their achievements must be numerous, that is why the singer cannot recount all of them.

Usually, when personalities are praised at the amar arena, they are expected to come out and shower gifts on the songster in appreciation. In the following excerpt therefore, the singer expresses his optimism that he has eulogized some great achievers whom he is sure would certainly reward him handsomely. He therefore states:

Tiv

Mtema kon hen

Ape me ker kwagh

Ken-ken-ken,

Abunde ga.

\section{English}

I'm lying in ambush for game

Where I must see game to shoot

Without fail,

This is obvious.

This metaphorical analogy means that, he has sung praises of trustworthy and generous personalities and is therefore optimistic of being adequately rewarded.

Yet another display of heroism is illustrated in our next excerpt, where Shôwua Azômon Gema, one of the personalities who attended the amar (concert) is said to have "beheaded shagba" (prestige). The singer puts it:

\section{Tiv}

Shôwua wan u

Azômon Gema,

Gber shagba ityough

Gbihi, akende ooo!

\section{English}

Shôwua, son of

Azômon Gema,

Has beheaded shagba (prestige)

And dropped it down ooo! 
The use of personification above shows that the addressee has attained the highest level of achievements by Tiv traditional standards. He has done all that a man needs to do, in order to gain recognition from far and near. He can thus be said to have literally conquered and then "beheaded shagba" (prestige).

The inyamtswam dance is used in checking the behaviour of members of the community. Tiv tradition has it that anyone who is guilty of using witchcraft unilaterally to harm or kill another person cannot perform the inyamtswam dance. Only those who have been cleared by the elders of any wrong doing are permitted to perform this prestigious dance.

Lamentation is a recurrent motif in Tiv heroic songs because the Tiv do not only praise the living, but equally praise great achievers who left indelible marks in the lives of individuals or the community as a whole while alive. This category of songs could be referred to as 'praise laments'. The Tiv belief that deaths in the community are usually due to the activities of the mbatsav (witches and wizards) is again illustrated in the following excerpt:

Tiv

Ajayi u Ikyoive Akortse, Kpaa a yem ee

Akendem tsa mgbe vaan,

Wan u Gom, mama wam Mama huan nen mliam, Mo wen me vaa gbem

Tsô ior a kav asema ooo.

\section{English}

Ajayi the son of Ikyoive Akortse,

Too, has gone

He has left me and I'm mourning

Daughter of Gom, my mother,

Stop weeping

I'll weep unceasingly,

Till the culprits realize their guilt ooo.

The singer promises in the last two lines above to keep tormenting perpetrators of this act with his wails, until their guilt overwhelms them.

In the next excerpt, the singer again expresses his predicament as the indyer once again announces the death of yet another hero, Utela Dôhô. Consequently, the singer is restless and cannot sleep. He sings:

Tiv

Mnyôr me yav,

Mnyam ka me vam ashe ga,

Tsa $m$ ungwa indyer

Itsa imo kaan er:

Takuruku anyam azenga,

Tile, tile jigh-jigh.
English

I retired, to sleep,

But sleep eluded me,

Then I heard indyer;

It kept saying:

Takuruku, the tiger,

Stay and wait for your brother.

The indyer is here calling on Takuruku, the father of Tiv to make way for one of his sons, who is on his way to the spirit realm. "Takuruku was a great warrior and a hero of incomparable status, so he is respectfully called Takuruku anyam azenga", meaning that he was a dreaded "Tiger". The tiger and lion are both kings of the jungle and are thus metaphors of strength and might. It is therefore logical that the Tiv refer to great achievers as either lions or tigers. The singer advises that the frequent deaths in the land should be checked, in order to move the Tiv nation forward.

Inyamtswam festival dance is anchored on the belief that poverty is a weakness and an evil. The person who breaks free from it must therefore have fierce skills and strength comparable to those of the inyamtswam (dangerous wild animal). In the next excerpt therefore, the poet states that Anom Guuja is a great achiever that has attained enviable heights in the community. He has thus become inyamtswam and therefore cannot be stopped from going further with his exploits, even with 'thorns'.

\section{Tiv}

Or a za kaam Anom Guuja,

A kar kwagh u shagba

Je gande.

Mbaagwa ve gema kôrôn

Sha mboho.

\section{English}

Someone tell Anom guuja,

His achievements

Are unequalled

Mbaagwa now suppress him,

With thorns.

The issue of wickedness in the land is again depicted in our next excerpt. The poet opines that the Tiv nation is not making any significant progress because there are too many vices. He indicts the leaders over wicked acts that have become prevalent in Tiv land. The elders no longer protect other people's children, when they are exposed to imminent danger. Consequently, the poet likens such wicked elders to 'hyenas', 'foxes' and senseless killers. The song reminds 
the Tiv people that they have abandoned their value system and therefore "Bad times have set in". They must therefore urgently retrace their steps in the interest of future generations. He states:

Tiv

Mbashôr nyôr ioor cha-cha,

Gema kôrôn ivo

I angbianev tyôr;

Mbaza mba kera ye luam

Mba lehe angbian ga,

Tar u bo nyôr;

Usambe lumun er

Iwua wue-er,

Ve lumun er iwua wue er;

Mbagbar nyôr anyam-kyegh

Ve gema kôron ior ikyegh ooh.

\section{English}

Mbashôr have all become hyenas,

Stealing goats

From their brothers' pens;

Mbaza no longer

Share food with their neighbour;

Bad times have set in;

Usambe approved

Senseless killings,

They have approved senseless killings;

Mbagbar have become leopards

Stealing other people's fowls.

The indyer is again brought into service at the amar of Nomishan Ukande. His might is demonstrated in the fact that the indyer is sounded as his wife, Ugber Ukor appears in the arena. As earlier stated in this work the indyer is not a common musical instrument and is thus sounded only at special occasions. The celebrant must therefore be an important personality indeed. He is thus being honoured with several praise names as we see below:

\section{Tiv}

Tor ka Achineku,

Mngerem ma sha awuha;

Tor ka begha man anyam,

Tor ka nor u tar ooh!

\section{English}

The king is fire and

Water at rapids,

The king is lion and tiger,

The king is an elephant oooh!

In the above excerpt, the strength, wealth and influence of Nomishan Ukande are so great that the poet likens him to "water at rapids", lion and tiger. This is another instance of using metaphor and hyperbole, which are common features in Tiv heroic poetry.

Yet another display of greatness is at the amar (concert) of Amase Yônkyô. The singer states that the celebrant's wife was adorned with 'tukure' before coming into the arena for her performance. The 'tukure' are strings of beads that are endowed with some mystic powers and are usually kept where the community's witchcraft items are stored. It is believed that each bead represents a human head. If a seed gets missing, it must be replaced by one death in the family responsible for the loss. It is therefore only great men that have the 'tukure' displayed at their amar as stated below:

\section{Tiv}

Mbaduku yar amar,

Atorough Kor har

Ingyôr na tukure shin tembe,

Kpire i gbidye

I kôrom a wan oooh.

\section{English}

Mbaduku attended the amar,

Atorough Kor

Adorned his sister with tukure

Kpire bird squawked,

Someone, hold my child - oooh.

The tukure which is mentioned above in line three is also believed to have the ability to make the person wearing it to radiate extra-ordinarily in the eyes of the audience. The poet further states that when the tukure was displayed on this occasion, the bird, kpire began to squawk. Kpire itself is a mystery bird that the Tiv associate with tsav (witchcraft). The cry of the kpire heralds the appearance of something spectacular. Sometimes its cry also alerts the people of an impending death within the community.

The heroic status of yet another great achiever, Shima Nomanyam is equally being captured in the next song as the poet states:

Tiv

Shima u Nomanyam Vembe, Dugh or ityough hen kpe Mkula,

Awambe sen nyôr shin Amile

Mbagbar u cii gudu-gudu,

\section{English}

Shima Nomanyam Vembe

Beheaded a man at the bank of Mkula,

Blood flowed into river Amile,

Mbagbar are trooping, 
Usambe gudu-gudu.

Atsem Vembe, nenge

Er a honom sha jime inyinya,

Wan u Mbajun kar

A nambe icham sha ivo

Me kera yer ne ga,

Vembe hemba wanger-wanger,

I ver ashe, i nenge oooh.
Usambe are trooping.

Look, Atsem Vembe

Is posing on a horse's back,

Daughter of Mbajun

Has offered me a goat,

I won't hide it from you,

Vembe is clearly the greatest,

People should watch out oooh.

Beheading of human beings from neighbouring tribes was considered heroic among the girinya (warriors' cult) in some parts of Tiv. In the above excerpt therefore, the celebrant is probably a girinya dancer and is said to have "Beheaded a man..." in the past. Also by successfully hosting the amar and appearing majestically on a horse, his achievements have made his age-mates to lose their faces. They grudgingly acknowledge his supremacy as they are filled with shame. The celebrant's wife is so generous that she rewards the singer with a goat.

\section{Conclusion}

Tiv oral poetry is a genre that is practised in many Tiv communities and comes in different forms, performing different functions. Generally, every activity of the African is accompanied by one form of poetic performance or the other. Tiv heroic poetry is thus aimed at extolling the virtues and highlighting the attributes of prominent sons and daughters of the community. This effort is meant to encourage people to strive to achieve great feats so that they can be recognized in their communities and thereby bring about the progress and development of the Tiv nation.

\section{References}

Abraham, R. C. (1940). The Tiv People. London: Crown Agents

Babajo, A.K. (2011). Orature: Meaning, Nature and Forms. Kaduna: Slimeline. Ltd.

East, R. T. (2003).The Akiga Story: The Tiv as Seen by one of Its Members. Ibadan: Caltop

Jenkwe, T. E. (1998). Yanmoel Yashi: A Study of Tiv Oral Poetry. Aba: Vitalis, 1998.

Keil, C. (1979). Tiv Song. Chicago: U.P.

Ker, A. (2002). Tiv Poetry and Politics: A Study of Tarker Golozo. Abuja: AKIA Books

Kunene, D. P. (1971). Heroic Poetry of the Basotho. Oxford: U.P.

Nkem. O. (2008). Preface to Oral Literature. Onitsha: Africana First Publishers 